\title{
Using the ACRL Framework for Information Literacy to foster teaching and learning partnerships
}

\author{
Allison Fullard ${ }^{1}$ \\ afullard@uwc.ac.za ORCID: orcid.org/0000-0002-1725-3878
}

\begin{abstract}
Received: 16 January 2017
Accepted: 14 February 2017

The Association of College and Research Libraries' (ACRL) Framework for Information Literacy in Higher Education presents scope for deepening the conversations and achieving more productive collaborations between lecturers and librarians. These transactions are significant for the ongoing efforts to create and maintain a sustainable programme for information literacy within higher learning. It is suggested that librarians and lecturers might use the Framework as a kind of heuristic resource to bring to the surface or make visible the processes and practices in knowledge making that may be tacit or unintelligible for students. Based on a series of interviews with lecturers across different disciplines, this paper explores the synergy between the conceptual frames of the Framework and the lecturers' strategies to bring about the kinds of literacies that are valued as generic graduate attributes needed in the twenty-first century.
\end{abstract}

Keywords: ACRL Framework, learning literacies, graduate attributes, embedding information literacy, multiliteracies

\section{Introduction}

Reports of frustrations in working within the limitations of the 'one shot' information literacy training session are legion, both locally and abroad (De Jager \& Nassimbeni 2005, Saunders 2012, Salisbury et al. 2012). The librarians at the University of the Western Cape (UWC) have been attempting for some time to interest lecturers in partnering to embed information literacy within academic curricula in order to position students for ongoing lifelong learning. In recent times, they have been aided in this endeavour by an institutional push towards development of generic graduate attributes. These are the overarching "qualities, skills and understandings ... that go beyond the disciplinary expertise or technical knowledge" (Bowden et al. 2000). In 2010, the UWC Charter of Graduate Attributes was collaboratively produced and promoted by the Directorate of Teaching and Learning. Lecturers are encouraged to develop graduates that are "inquiry focused", "critically and relevantly literate", "autonomous and independent" thinkers capable of working collaboratively and "communicating across difference", with ethical and "social consciousness" (UWC 2010). Information literacy provides the bedrock for independent, critical thinking and is referenced directly or indirectly within several clusters of graduate attributes (De Jager \& Nassimbeni 2005, Barrie 2012, Salisbury et al. 2012). Despite this important relationship, librarians can find it difficult to engage academics on the precise ways in which ongoing exposure to and assessment of information literacy is crucial for attaining these core institutional values, whether viewed as attributes or learning literacies.

This article presents preliminary findings from a project funded through an institutional Teaching and Learning research grant. The end goal of the project is to develop a short course for lecturers to help them to embed literacies within their curricula in order to cultivate the graduate attributes desired by the university. Such an outcome requires collaboration with faculty librarians. The library initiated the project with a view towards cementing its role in improving student learning. In all universities, but particularly at a South African institution that predominantly serves first-generation students, librarians experience considerable demand from individual students who are encountering new subjects that are presented to them with arcane terminology and distinct knowledge practices. This is the "daily struggle of translation between the organised conceptions of knowledge and the efforts of all students to engage that knowledge" (Elmborg 2006: 198). The term 'academic literacies' refers to the meaning-making processes that are summonsed for the myriad of cognitive learning tasks and proficiencies that are necessary to produce knowledge. These include all forms of reading, writing and working with diverse kinds of texts in social settings to accomplish a specific purpose (Lea \& Street 2006). It has been noted that subject matter teachers "fail to make explicit the complex inquiry and literacy practices in which disciplinary experts engage" (Goldman \& Scardamalia 2013: 261, Jacobs 2005).

\section{Literacy, or literacies?}

Academic, information, critical and digital literacies tend to be separately conceptualised, researched and developed, with libraries of literature devoted to each. The emergence of such terms as 'transliteracy', 'metaliteracy', and 'multiliteracies' indicates a recognition of the convergence of literacies to address the blurring boundaries of real and virtual, public and private, work and leisure in the twenty-first century (Andretta 2012, Mackey \& Jacobson 2011, Kalantzis \& Cope 2012). The terms suggest both an expanded range of literacies needed for managing life in the twenty-first century and also that there are linkages and relationships among these literacies. As Coiro et al. (2008: 14) asserted, new literacies are "multiple,

1. Allison Fullard is Deputy Director, Library Services, University of the Western Cape 
multimodal and multifaceted. It becomes increasingly difficult to think of literacy as a singular construct that applies across all contexts". A plurality of literacies is essential for meaning making within the context of global citizenship and the celebration of social and cultural difference and available technology (Galloway n.d).

The JISC-funded Learning Literacies for a Digital Age project has been influential in presenting the concept of 'learning literacies' as a cluster of inter-related capabilities. The researchers took a wide scope of literacies, including digital, information and media literacies, within their review of over thirty different competency frameworks; they also audited the provision of literacies education in United Kingdom (UK) higher and further education institutions (Beetham, McGill \& Littlejohn 2009, Littlejohn, Beetham \& McGill 2014). The project explored the question of how tertiary institutions are preparing their students with skills and capabilities that are most needed for their future lives. A key finding from their examination of existing UK practices and frameworks was that there was poor embedding of literacies into the curriculum and weak integration of information and digital literacies with academic literacy. Littlejohn, Beetham and McGill (2012) reported that even the "exemplary" SCONUL framework ${ }^{2}$ has not been effectively integrated into curricular programmes. Reports from South African surveys indicate that many of the library-initiated information literacy programmes are generic or stand alone, and that meaningful partnership is difficult to attain (De Jager \& Nassimbeni 2002 and 2005, Jiyane \& Onyancha 2010).

\section{Literacies for learning}

Most, if not all, undergraduate students need explicit guidance and repeated practice to develop their capabilities to accomplish high-level academic tasks (Boughey 2005, Leibowitz 2004). Especially through use of student-centred pedagogies such as inquiry-focused learning and resource-based learning, lecturers expect their students to gather, evaluate and synthesise information from diverse sources independently, but might underplay the skills required to accomplish these tasks (McGuinness 2006, Saunders 2012). The one-shot information literacy lecture-demonstration does not begin to bridge this gap.

A perennial problem is that, despite the evolving scholarship on literacies, the notion of literacy as a technical skill residing in individuals is not easily shifted and, in some measure, accounts for the lasting perception among lecturers that literacy development belongs outside of the curriculum (Wingate 2006, Barrie 2007). Until literacies are understood as situated, socio-cultural systems of meaning making and a means of identity formation within disciplinary contexts (Lea \& Street 2006, Ivanic et al. 2009, Lloyd 2012), lecturers might discount literacies as the primary means to achieve deep learning and transformative educational experiences for students.

The educational rationale for embedding literacies within academic curricula is well established (Baik \& Greig 2009, Jacobs 2005, Bundy 2004, Gunn, Hearne \& Sibthorpe 2011, Wingate 2006, Salisbury et al. 2012). Information and knowledge are produced, encoded, distributed and valued in different ways according to disciplinary community practice. The behaviour, explicit guidance and expectations of lecturers are the primary shapers for development of student literacies. Accordingly, lecturers are key actors and enablers (Grafstein 2002, Gunn, Hearne \& Sibthorpe 2011). Littlejohn, Beetham \& McGill (2014: 132) made the same claim for digital literacies:

We can draw a key principle from this evidence that emergent digital practices could be influenced by academic as subject experts ... How can academics model the identities, stances, strategies and capabilities that learners require for effective knowledge practice?

The primary channel for literacies education in South Africa is expressed either through the mandate for 'critical crossfield outcomes' defined as "generic outcomes that inform all teaching and learning" (SAQA 2000), or through the discourse of graduate attributes which speak to the goals of higher learning. From discussions with faculty-based teaching and learning specialists, it transpired that lecturers might acknowledge information literacy by listing it as a generic outcome of their modules but have not yet collaboratively engaged with teaching strategies to develop and assess graduate attributes across an academic programme. Such reports from local experience, coupled with accounts in the literature (UWC 2016: 16, Salisbury et al. 2012, Speight, Luckovic \& Cooker 2013, Barrie 2007), indicate that lecturers find it difficult to create and implement coherent programmes for the development of graduate attributes. The research project under review aims to design material that will form part of a broader short course on teaching and learning that is mandatory for all new lecturers during their two-year probation period.

Within the present turbulence caused by student protests and calls for the decolonisation of higher education, it is likely that departments will be reviewing academic programmes with a view towards renewal of the curriculum and refinement of pedagogical approaches. Building the capacity of students to participate and engage with the knowledge of a field, sometimes referenced as "epistemological access" (Boughey 2005, Morrow 2009), also implies expanding literacies which enable meaning making and capacity for learning. Cope and Kalantzis (2010:100) wrote of the potential of multiliteracies to empower individuals who "can navigate change, and make and lead change rather than be knocked about by it". This calls to mind Paolo Freire's (1984) emancipatory vision of critical literacies that challenge dominant and oppressive assumptions.

2. The Seven Pillars of Information Literacy, issued by the Society of College, National and University Libraries (UK) 


\section{The ACRL Framework for Information Literacy for Higher Education}

To add further complexity to the foregoing discussion, the digital age is transforming the fundamental nature, dimensions and roles of information practices (Lankshear \& Knobel 2007, Kress 2010). The Framework for Information Literacy for Higher Education (ACRL 2015), henceforth referred to as the Framework, was formally adopted by the Association of College and Research Libraries in 2016 as a response to the dynamic changes in the information ecosphere. It represents a firm grasp of the inclusive, participatory ethos that now informs communication and social discourse in academia. The threshold concepts lend themselves to the notion of plural literacies and towards transformational learning experiences for lifelong learning.

The Framework has re-envisioned the goals of information literacy and fundamentally seeks to help students to understand the knowledge-making process and to strengthen their own facility when it comes to using and creating diverse information or knowledge products. The six concepts that comprise the Framework act as lenses through which to understand the work that is being done by students when they tackle study tasks. In this way, the concepts help to foreground some of the conceptual understandings that tend to be implicit for lecturers who are academically expert. Each concept is represented by a set of associated knowledge practices and dispositions that characterise the exercise of each concept as a student moves from novice to expert.

Many articles focusing on the impact of the Framework on library practices have appeared in predominantly North American Library and Information Science (LIS) journals (Beilin 2015, Foasberg 2015, Dempsey \& Jagmah 2016, Swanson 2017). The remainder of this article focuses on the individual concepts from the Framework and illustrates their relevance for literacies for higher learning. This is accomplished by showcasing selected quotes from a series of interviews with lecturers from different faculties. The interviews formed an important data gathering component of the above-mentioned research project. The analysis is also supported with ideas from the LIS and educational research literature.

\section{Method}

With a view to designing the short course, it was important to investigate how innovative lecturers are already addressing the teaching and assessment of graduate attributes that the UWC Charter of Graduate Attributes (2010) identifies as desired learning outcomes. The intention was to discover how such learning literacies are developed. With guidance from the Director for Teaching and Learning at UWC, a set of interview questions was prepared to guide a semi-structured, freeflowing discussion (see Appendix). The Director also invited selected individuals to be interviewed by one or both of the researchers for the literacies project. Twelve of these consented and ethical clearance to conduct the interviews was duly secured.

The twelve participants were drawn from six faculties and the Writing Centre, and were specifically identified as distinguished teachers. Their expertise was indicated in one of four ways: the participants had won prestigious Higher Education Learning and Teaching Association of South Africa (HELTASA) national awards; taught in regional professionalisation of teaching and learning courses; were known on campus for innovative teaching practices; or for their work on developing students' literacies and graduate attributes. Only one invited lecturer did not agree to be interviewed.

The interview questions aimed to stimulate discussion on their teaching approaches and experiences in order to distil some insights into how disciplinary literacies were taught and assessed. In effect, over the course of an hour-long discussion about literacies, the author was looking for linkages with the UWC graduate attributes. Table 1 indicates the academic departments in which the interviewees were based and shows the broad linkage between the individual graduate attributes and the interview questions.

Table 1 Mapping the interview questions to the Graduate Attributes (GA) (UWC 2010)

\begin{tabular}{ll}
\hline $\begin{array}{l}\text { Physiotherapy- Dentistry - Linguistics - History x2 - Business \& Finance - Education - Gender Studies - Biodiversity - Science - } \\
\text { Writing Centre - English for Academic development }\end{array}$ \\
\hline $\begin{array}{ll}\text { GA1: Critically and relevantly literate; } \\
\text { (Seek, discern, use and apply information) }\end{array}$ & $\begin{array}{l}{ }^{*} \text { How are literacies scaffolded? What literacies are problematic for lecturers? } \\
\text { * What changes in reading, writing, presenting information? }\end{array}$ \\
\hline GA2: Autonomous, independent thinkers & $\begin{array}{l}\text { * Can students discern authoritative voices? } \\
\text { * How may students critique knowledge or take a position? }\end{array}$ \\
\hline GA3: Inquiry focused; knowledge producers & $\begin{array}{l}\text { * How do you use inquiry-focused learning? } \\
\text { * Do you think it's important for students to be able to produce knowledge? }\end{array}$ \\
\hline $\begin{array}{l}\text { GA4: Skilled communicators; engaging } \\
\text { across difference }\end{array}$ & \begin{tabular}{l} 
* How do you use social media in your teaching and learning? \\
\hline
\end{tabular}
\end{tabular}

After the interviews were transcribed, Atlas.ti was used to help organise the coding process for qualitative analysis. Topical codes were deductively applied to the transcripts based on key concepts from the literature related to graduate attributes, new literacy studies and authentic learning. At the same time, codes derived from the Framework concepts were inductively applied. In this way, it became possible to determine whether the concepts presented in the Framework might speak both to the institutional graduate attributes and to the specific challenges that the lecturers were reporting. Table 2 provides a broad overview of the mapping. It is important to stress that, although the Framework concepts are expressed as distinct, in practice they are overlapping, layered, and related. 
Table 2 Mapping of Framework concepts to Graduate Attributes (GA)

\begin{tabular}{ll}
\hline $\begin{array}{l}\text { GA1: Critically and relevantly literate; } \\
\text { (Seek, discern, use and apply information) }\end{array}$ & Scholarship as a Conversation \\
\hline GA2: Autonomous, independent thinkers & Authority is Contextual and Contested \\
\hline GA3: Inquiry focused; Knowledge producers & $\begin{array}{l}\text { Research as Inquiry } \\
\text { Searching as Strategic Exploration }\end{array}$ \\
\hline $\begin{array}{l}\text { GA4: Skilled communicators; Engaging } \\
\text { across difference }\end{array}$ & $\begin{array}{l}\text { Information Creation as a Process } \\
\text { Information has Value }\end{array}$ \\
\hline
\end{tabular}

At the time of the interviews, none of the participants had previously read or heard about the ACRL Framework. The author's own engagement with draft versions of the emerging Framework had been at an early stage of its development. None of the questions anticipated or prompted connections with the ACRL threshold concepts. The intersections between these accomplished lecturers' strategies to develop graduate attributes and the ACRL concepts only became apparent after greater acquaintance with the Framework.

\title{
6 Discussion of findings
}

The following section presents each of the six Framework concepts, illustrated with tables containing quotes from the interview transcripts. The quotes were selected to indicate their links with the concepts and knowledge practices of the Framework, thereby highlighting the relevance of these for developing learning literacies comprising information, academic, critical and digital dimensions.

\subsection{Scholarship as a conversation}

New students may arrive at university with fixed ideas about knowledge which have to be disrupted. Dede (2008) spoke of a "seismic shift in epistemology" while Elmborg (2003: 74) stated that undergraduates "rarely understand that knowledge is dialogic, that it is negotiated in the discussions, disputes and disagreements of specialists". Students view knowledge as "something monologic - even monolithic, a thing that can be learned whole" (Elmborg 2003: 74). This idea is reflected in the lecturers' comments.

Table 3 Scholarship as a conversation: excerpts from the interview transcripts

\begin{abstract}
Once students understand that everything is open for debate - and that the relationship between facts is open for discussion - it opens their mind to the possibility that we can have a critical conversation about anything. (Physiotherapy)

Conversations are imperative for learning. You can't really know without being in collaboration with someone, whether with texts or your peers. I don't think that we model that - about learning through conversations. (Dentistry)

[Hypothetically addressed to students] You're entitled to have a viewpoint ... you know quite a lot about it; develop a little bit of confidence and try to express that and just use those authors for support because you've actually come up with something here. (History)
\end{abstract}

And now I think that the idea is more that we ask students: "Well, what do you think about this?" And so it becomes more of a conversation than a one-way flow of information. (Business)

Scholarship as a conversation essentially refers to the dialogic nature of knowledge: as time passes, "ideas are formulated, weighed and debated against each other" (ACRL 2015: 8). This critical consciousness was something that the Physiotherapy lecturer was trying to awaken within his class. He took the position that all ideas are eminently improvable. The Dentistry lecturer was conscious of the importance of dialogue for learning. The dialogue may be external with others or internal with authors while reading. Such dialogues force one to interrogate what one already knows and has experienced. The History lecturer attempted to coax the students' authentic voices. It is important to prepare them to be conversant in the discipline by deconstructing the discipline. This means showing how an expert does these things, by explicitly modelling them and giving students practice and feedback. The Business and Finance lecturer wanted her students to engage in discussion. She posed a question on the e-learning platform and allowed two days for students to discuss the question virtually and then prepared a lecture based on the students' responses. In this way she was recruiting what they already knew and helped the class to become conversant with associated ideas before the lecture supplied the theory. Other lecturers reported using social media to get their students to communicate ideas - not necessarily in academic vein - so that students articulated their understanding.

Several of the threshold concepts invite opportunities for deepening students' cultural appreciation for the purposes of attribution and referencing, something that is far more meaningful than the plagiarism detection systems in force in many institutions.

Citing the source of ideas is a deeply embedded 'given' within academic culture, and as such, may not be critically deconstructed for students. Consequently, many students have only a surface (quasi-legal interpretation) understanding of what plagiarism involves. Coming to an awareness of information as a 
cultural product and positioning their information engagement within this context allows students to develop a deeper understanding of academic requirements (Blackmore 2010: 7).

Librarians and lecturers may use this concept to teach attribution of source so that the underlying purpose of referencing sources is understood.

\title{
6.2 Authority is contextual and constructed
}

Are all voices in the conversation equal? The second concept is more critically nuanced as it deals with power. How do we encourage students to become autonomous, independent thinkers capable of discernment? Mezirow (1997: 7) claimed that, rather than acting uncritically on the received ideas and judgements of others, "thinking as an autonomous and responsible agent is essential for full citizenship in democracy and for moral decision making in situations of rapid change".

\section{Table 4 Authority is contextual and constructed: excerpts from the interview transcripts}

\begin{abstract}
I think you have to show them who the authorities are, you can't just assume that they'll know who the chiefs of the tribe are. (Writing Centre)

All texts arise out of social, political, economic circumstances - so they're all context bound, culturally bound and originated. (Education)

Because thinking is socially constructed, it can change, that we're not stuck with ideas because, parsimoniously and in a principled way, theory is reconstructed and developed through research. (Linguistics)

It's about learning to understand the other person's belief system before you criticise it; and I suppose learning to feel some discomfort with challenges to your own belief system. (Natural Sciences)

It's important that you're able to defend why you think some piece of information is better than another and that you can explain that both to a colleague and to a patient. (Dentistry)

The focus on themselves in context makes them think a little bit more carefully about their own biases, assumptions and prejudices. (Gender Studies)
\end{abstract}

Each discipline is framed by powerful discourse with recognised figureheads and systems of thought. The head of the Writing Centre is an academic development specialist who felt that students need to know who the "chiefs of that tribe" are, the giants who have gone before and shaped the contours of the discipline. If one doesn't know the terrain and who the "chiefs" are, can one participate in the discourse or create knowledge that is valued by a community? It is also true that our own knowledge is partial and incomplete, based on asymmetrical power relations. Economic barriers have served to restrict participation in the established canon and ongoing scholarly debates. This space is also being claimed by the call for decolonising of higher education as students demand that knowledge domains are recognisable to them and speak to their experiences. While the canonical voices might be dominant, Scott (2009:4) suggested there is space for teachers to adjust their practices, from curriculum design to pedagogical arrangements in the classroom, in order to "affirm the presence of a growing, changing and increasingly diverse student body".

The Linguistics lecturer emphasised that the dominant voices or ways of thinking are not fixed. One of the critical teaching activities at university is to help students understand that thinking is constructed and that, because its socially constructed, it can change; that we are not stuck with ideas but can think our way through problems. The lecturer in the Natural Sciences implied that one must have knowledge before one can critique, while the Dentistry academic maintained that one should also be in a position to defend one's stance. The Women and Gender lecturer was at pains to help students recognise their own assumptions and bias. As Swanson asked, "how do we know what we know?" (2010). The frame 'authority is constructed and contextual' seems already to be part and parcel of the academics' thinking.

\subsection{Research as inquiry}

This concept feeds well into the current trend towards undergraduate research and inquiry-focused pedagogies (Herrington \& Oliver 2000, Bundy 2004). Lecturers and librarians play a role in developing students' familiarity with sources of evidence, methods and modes of discourse so that they can "contribute to the conversation at an appropriate level" (ACRL 2015: 8). There are different stages in development of students' expertise in inquiry, beginning with synthesis and recapitulation of available information.

The Director of the Writing Centre complained that too often the focus is on the content rather than on the principles that shape the knowledge and how it is made, so that students "end up just trying to learn all the stuff". Others complained that colleagues are sticking to traditional frameworks, setting bounded tasks of responding to prescribed readings, performing highly-structured tasks done by generations of students. The excuses given included time constraints, the limitations of first years, and the difficulty for students to generate their own questions. The antidote is authentic teaching and learning, when learners are immersed in new experiences, connect knowledge with personal experience, and are asked to apply their learning in real-world contexts (Herrington \& Oliver 2000). The Biodiversity and Conservation Biology lecturer accomplished this with first-year students by asking them to look after a goldfish for the year. In this way, students negotiated their own understanding by applying theories to problems they encountered during this experience. 
Table 5 Research as inquiry: excerpts from the interview transcripts

\begin{abstract}
The problem of a stuffed curriculum is that students don't learn the principles that shape the knowledge. They aren't shown how to select, re-contextualise, move around the stuff, and make something new of it - they don't see the system of meaning. (Writing Centre)

It's a first year course.... I believe in starting to put the testable questions, the idea of a hypothesis, putting the research method in, and the fact that the information is there but you have the right to test its authenticity. (UG research) (Biodiversity and Conservation Biology)

It's going and saying, well, now you have this theory, now you have this case and scenario - how are you going to apply that theory to the case scenario, and what is your opinion or reflection from that experience? (Physiotherapy)

And that's what I loved about this, was trusting the students to do their own discovery - and they ran with it, they loved it. "Thank you for putting your trust in us to do self-learning". (History)

If one of my ideal graduate attributes is an ability to do independent research, what do I need to be doing in first year, second year, third year so they can do that? Is my curriculum helping the students to produce knowledge? (Business)
\end{abstract}

The Physiotherapy lecturer also tried to make theory purposeful and transferable in new contexts. He was looking for analytical, logical reasoning in difficult clinical cases. This application of reasoning helps students to understand the nature of the disciplinary problems and which knowledge is applicable. Inquiry-focused or discovery-based learning implies trust; the History lecturer said, "I want to reach the students; I want them to enjoy themselves. I want to spark their interest and I want them to get a sense of capacity. That's all I want". She understood that, when students create something new, they are producing knowledge and she considered herself changed as a result of conversations with her students. The Business Studies lecturer's comment about sustaining and growing the practice of student research over successive years is important as one of the aims of the forthcoming short course is to embed literacies and GAs throughout the academic programme.

\title{
6.4 Information creation as a process
}

This threshold concept offers wide variation of learning opportunities for students at various stages of academic development, in terms of their evaluation and creation of information products. Students should understand that the quality and usefulness of a particular piece of information is determined by the processes that went into making it. Librarians are well-placed to make visible some of the elements in the value chain of information that influence the reception and effectiveness of such products (Swanson 2017). When students are fully aware of options for producing and sharing information, they may make more informed decisions regarding the suitability of the information they use in different contexts. As producers of information, they understand that the creation process will determine the ways in which their work is used and valued. The purpose of the communication should match the desired audience. Kress (2010) called this process "design". We construct texts of various kinds on the basis of decisions on the arrangement of available words, images, expressions and grammars and shape these according to our interest, need and social context. This concept is related to the educational idea of writing as a process, in the sense of refining a piece of writing by drafting and shaping it through a number of iterations. In so doing, one crafts texts to convey information appropriately for a particular audience.

Table 6 Information creation as a process: excerpts from the interview transcripts

\begin{abstract}
We use a process approach to writing, so tutors will respond to a minimum of one draft, but often two or three. (English for Educ. Dev.)

I reconsider and say, ““OK, well, now that you've done this and you haven't done very well, you can rewrite it” (Gender Studies)

Whether they do it through WhatsApp, Google docs, or through a blog - they are encouraging each other. And the motivation component is very important in collaboration. (Business and Finance)

I think we've got to be more open and more flexible with what resources they do bring into their studies and try to find ways of doing that. (Linguistics)

I've started thinking about assignments now as conversations and as public performances, rather than this thing that you do and you give to a lecturer and he marks it and gives it back to you. (Physiotherapy)
\end{abstract}

They create notes ahead of time to go into the Second Life so we can deal with it there as avatars in a virtual discussion. (Biodiversity and Conservation Biology)

The Business Studies lecturer expanded that writing process into a collaborative process, as she found that collaboration improved student motivation. Several of the interviewees were using platforms that facilitated collaborative input and that enabled interactive feedback and comments, encouraging dynamic exchanges for increased levels of participation and inclusion, vital for twenty-first century literacies. In the context of the use of appropriate register in specific 
contexts, the Linguistics lecturer remarked that she thought students understand those principles and had a natural feel for it because they were constantly switching and mixing languages. Her classes were also shown how to adapt to the demands and expectations of different contexts and audiences. One of the characteristics of authentic learning is the opportunity to perform or make public the learning that has been achieved. The Physiotherapy lecturer promoted knowledge sharing. Finally, the seismic shift in Information Communication Technologies (ICTs) enables powerful ways of presenting information. The Biodiversity lecturer used Second Life platforms to immerse his students virtually within remote ecologies. The class met in virtual reality. At the end of the course, they were required to produce a digital story that integrated tables, graphs and data models and share this on YouTube. He insisted that all re-purposed images and sounds be correctly acknowledged and appropriately licensed for public sharing.

\title{
6.5 Information has value
}

What understandings of value are uppermost in students' minds? The ethical dimensions of authorship that are traditionally understood within society are experiencing pressures arising from changing social practices. Students' experience of file sharing and creatively remixing digital material for new purposes will shape their ideas about ownership of content. The fluid nature of digital texts means that they are inherently mutable, and transferable and this fluidity unsettles notions of authorship (Kress 2010: 21). Digital media is reconstructing the relative positions of authors and readers, as a result of options for collective authoring, annotation, tagging and remixing. Students should understand that they have responsibilities as both consumers and creators of information based on the work of others. They respect the obligation to cite and acknowledge words, ideas and products of others, valuing the skills, time, and effort needed to produce knowledge.

\section{Table 7 Information has value: excerpts from the interview transcripts}

\begin{abstract}
All assignments that they do should be designed to be shared with other citizens. So the idea of citizenship is brought in and you are contributing to a knowledge commons and that's fundamental to this. We do the Creative Commons [licensing in] second and third year. And they have to put the Creative Commons licence into the images and they have to give the full trackback attribution, because this is really, really important. (Biodiversity and Conservation Biology)
\end{abstract}

If you have a problem and you solve that problem, you have an ethical obligation to share your solution with the rest of the world. Other people have the same problem. You would have been able to solve that problem if you had found someone's solution. I think that is also part of knowledge production. It's that sense that you make a difference by what you share. (Dentistry)

We encourage students to engage with NGOs and scientific activism which requires research or participation in extramural activities, protest marches or creating websites to promote critical engagement, such as anti-fracking or anti-nuclear events. They are expected to develop ideas from this and promote the NGO or a blog they have created. They maintain them and they retain their interest.... they remain involved. And their big push is to get this knowledge to the community. (Science)

One day people are going to be searching for your name when you apply for a job - what do you want them to find? And a lot of the students were coming up to me and saying I really need to change how I behave online, because they're starting to think about these issues very much. (Physiotherapy)

The norms of science require that research results are disseminated. As mentioned above, the Biodiversity and Conservation Biology course convener acquainted second- and third-year students with Creative Commons licences and emphasised that all images, ideas and music in their digital stories were correctly licensed and attributed before being uploaded to YouTube. The enormous disparities within the global economy are mirrored in highly unequal access to scholarly information. The sharing of knowledge was highlighted by the Dentistry lecturer.

Librarians can sensitise students to the strong possibility that their research strategy may be affected by restricted access as a result of unaffordable database costs. They can teach students how to find open access or freely licensed content and how to re-use this material ethically. Students need to know that their own information behaviour carries value. All online activity is subject to forms of tracking. The data trail generated by individuals' search queries and navigation is automatically captured. Consequently, this influences the information that is delivered, shared and presented to them. Because it is difficult to remain anonymous online, students should be sensitive to the implications of their online communications and how this affects their online profile.

\subsection{Searching as strategic exploration}

The final concept is quite sophisticated since there is crossover with most of the other concepts. Within the scope of their exploration, students have to remain critically conscious of the authority lenses at work within different contexts. They should come to understand the processes through which information is created, produced and distributed. They will also be aware that scholarly conversations take place in a number of unlikely places. Assessing the strengths and shortcomings of genres, forms and modes of textual and multimodal information may be tied to their reception in different contexts. Once these dimensions are well understood, discernment may be an easier task. Nevertheless, the norms within academia are slow to change, as pointed out by the Physiotherapy lecturer below.

There were noticeably fewer quotes coded with this Framework concept which is traditionally taught by librarians. Lecturers do not readily identify with this aspect, a feature also noted in a recent article (Swanson 2017). As scholars, lecturers have derived their own methods of sourcing relevant material, for example, through serendipity, networking, and 
active collaboration in the field. It is also likely that their evaluative 'nose' has been developed through years of scrutinising footnotes and references. Such methods are refined over years. As novices, students benefit from a series of learning opportunities with subject librarians to develop their familiarity with the chief sources of information in the field, search tools and methods. Students may also be exposed to citation management tools while searching so that they are able to organise and manage the sources of which they want to keep track.

Table 8 Searching as strategic exploration: excerpts from the interview transcripts

\begin{abstract}
I've got some colleagues who will say you shouldn't look at a blog. But if that blog is written by a clinician who developed specific interventions, like this particular technique carries this blogger's name, I think we should pay attention to their blog. When I talk to students, I let them know this. "This person, she's very influential in physiotherapy, her opinion is worth considering. When you know that she's written these books and she's written all of these papers- and we see that she has a blog. Just because it's a blog ... the medium doesn't determine the authority". (Physiotherapy)
\end{abstract}

They've got to show the reasoning process ... So if they type in a search query I want to know, why did you choose that search query? Why did you choose those words rather than these other words? (Business)

Well, we teach them how to use the internet, so we have workshops where we say this is how you develop a research question, this is how you use Boolean operators in a search query, this is how you look at search results to look at, so something with an .edu extension is possibly going to be a better source of information that something with a .com (Physiotherapy)

\title{
7 Conclusion
}

The focus of this paper has been on the ways in which the Framework might assist in surfacing and consolidating the capabilities implied by converging literacies or graduate attributes. This knowledge is salient for librarians charged with working toward embedding information literacy within academic curricula. Developing librarian-lecturer partnerships implies a common understanding of the challenges and shared points of reference. In the context of partnerships between social workers and teachers, Edwards (2011:33) termed this "relational agency that is mediated by common knowledge built in interactions at the points where the boundaries of practices intersect". The Framework can work to establish some of this meeting ground. The concepts and knowledge practices serve as a form of shorthand to reference what can be quite abstract territory in higher learning. That landscape encompasses the long-term educational goals for graduates, and the development of literacies that remain a latent power for interpreting, producing and communicating meaning in all manner of environments.

It is difficult for teachers, experienced and expert within the discipline, who "long since travelled similar ground in their own disciplinary excursions, to gaze backwards across thresholds and understand the conceptual difficulty or obstacles that a student is currently experiencing" (Land et al. 2006: 199). Without reifying the ACRL threshold concepts as distinct outcomes, this study illustrates their potential value to help lecturers and librarians pinpoint the modes of thinking and being that are helpful for engaging in disciplinary knowledge practices. On the other hand, limited exposure to concepts in educational theory and literacies scholarship might handicap librarians in their attempts to engage productively with faculty concerning information literacy (Bundy 2004, De Jager and Nassimbeni 2005, Simmons 2005, Elmborg 2006). The language and concepts presented in the ACRL Framework can serve as pivots or common meeting points around which the specific knowledge practices or dispositions desired by a lecturer and librarian might be more precisely evoked and discussed. The basis for this assertion is the resonance between the ACRL concepts and the pedagogical concerns of lecturers described above. The excerpts from interview transcripts point to areas of intersection and collaboration.

Encouraged by these findings, which were subsequently reinforced through a series of workshops with individual academic departments, library colleagues have developed an online tutorial, Exploring 21st Century Literacies (available at http://literacies4learning.uwc.ac.za). This tutorial is to be used within a short course facilitated by the Directorate of Teaching and Learning, which is mandatory for all new academic staff. It is anticipated that the librarians' role is one of partnering consultant that assists in designing learning opportunities and assessments that incrementally advance the development of the knowledge practices within a discipline. To prepare faculty librarians, several internal workshops have been held and one-on-one coaching is ongoing. In this way, we may be led to more active partnerships for embedding of information literacy concepts within academic programmes.

\section{Acknowledgement}

The author wishes to thank Prof Vivienne Bozalek for collaboration and support at critical points in this research project.

\section{References}

Association of College and Research Libraries (ACRL). 2015. Framework for information literacy for higher education. Association of College and Research Libraries. [Online]. http://www.ala.org/acrl/sites/ala.org.acrl/files/content/issues/infolit/Framework_ILHE.pdf (13 January 2017).

Andretta, S. 2012. Web 2.0: From information literacy to transliteracy. In Information literacy beyond Library 2.0. P. Godwin and J. Parker, Eds. London: Facet, 53-64. 
Baik, C. and Greig, J. 2009. Improving the academic outcomes of undergraduate ESL students: the case for disciplinebased academic skills programs. Higher Education Research \& Development, 28(4): 401-416. DOI:10.1080/07294360903067005.

Barrie, S.C. 2007. A conceptual framework for the teaching and learning of generic graduate attributes. Studies in Higher Education, 32 (4): 439-458. DOI:10.1080/03075070701476100.

Barrie, S.C. 2012. A research-based approach to generic graduation attributes policy. Higher Education Research \& Development, 31(1): 79-92. DOI:10.1080/07294360.2012.642842.

Beetham, H., McGill, L., and Littlejohn, A. 2009. Thriving in the 21st Century: Learning literacies for the digital age. Glasgow: Caledonian Academy. [Online]. http:www.jisc.ac.uk/media/documents/projects/llidareportjune2009.pdf (13 January 2017).

Beilin, I. 2015. Beyond the threshold: conformity, resistance and the ACRL Information Literacy Framework for Higher Education. In the Library with the Lead Pipe, 25 February 25. [Online]. http://www.inthelibrarywiththeleadpipe.org/2015/beyond-the-threshold-conformity-resistance-and-the-aclr-informationliteracy-framework-for-higher-education/ (13 January 2017).

Blackmore, M. 2010. Student engagement with information: applying a threshold concept approach to information literacy development. Paper presented at the 3rd Biennial Threshold Concepts Symposium: Exploring transformative dimensions of threshold concepts. 1-2 July 2010, Sydney, Australia. [Online].

https://www.academia.edu/1664881/Student_engagement_with_information_Applying_a_threshold_concept_approa ch_to_information_literacy_development (13 January 2017).

Boughey, $\bar{C}$. 2005. Epistemological access to the university: An alternative perspective. South African Journal of Higher Education, 19(3): 638-650.

Bowden, J., Hart, G., King, B., Trigwell, K. and Watts, O. 2000. Generic capabilities of ATN university graduates. Canberra: Australian Government Department of Education, Training and Youth Affairs.

Bundy, A. 2004. Australian and New Zealand information literacy framework: principles, standards and practice, $2^{\text {nd }}$ ed. Adelaide: Australian and New Zealand Institute for Information Literacy. [Online]. http://www.caul.edu.au/content/upload/files/info-literacy/InfoLiteracyFramework.pdf (13 January 2017).

Coiro, J. et al, eds. 2008. Central issues in new literacies and new literacies research. In Handbook or research on new literacies. J. Coiro, J., et al, Eds. New York: Lawrence Erlbaum: 1-22.

Cope, B. and Kalantzis, M. 2010. New Media, new learning. In Multiliteracies in motion: current theory and practice. D.R. Cole and D.L. Pullen, Eds. New York: Routledge: 87-104.

De Jager, K. and Nassimbeni, M. 2002. Institutionalizing information literacy in tertiary education: lessons learned from South African programmes. Library Trends, 51(2): 167-184.

De Jager, K. and Nassimbeni, M. 2005. Information literacy and quality assurance in South African higher education institutions. Libri, 55: 31-38. DOI:10.1515/LIBR.2005.31.

Dede, C. 2008. A seismic shift in epistemology. EDUCAUSE Review, 43(3): 80-81. [Online]. http://er.educause.edu/articles/2008/5/a-seismic-shift-in-epistemology (13 January 2017).

Dempsey, P.R. and Jagmah, H. 2016. I felt like such a freshman: first-year students crossing the library threshold. portal: Libraries and the Academy, 16(1): 89-107.

Edwards, A. 2011. Building common knowledge at the boundaries between professional practices: relational agency and relational expertise in systems of distributed expertise. International Journal of Educational Research, 50(1): 33-39. DOI:10.1016/j.jer.2011.04.007.

Elmborg, J. 2003. Information literacy and writing across the curriculum: sharing the vision. Reference Services Review, 31(1): 68-80. DOI:10.1108/00907320310460933.

Elmborg, J. 2006. Critical information literacy: implications for instructional practice. Journal of Academic Librarianship, 32(2): 192-199. DOI:10.1016/j.acalib.2005.12.004.

Foasberg, N.M. 2015. From standards to frameworks for IL: how the ACRL Framework addresses critiques of the Standards. portal: Libraries and the Academy, 15 (4): 699-717.

Freire, P. 1984. Pedagogy of the oppressed. New York: Continuum.

Galloway, S. n.d. C21 literacy: what is it, how do we get it? A creative futures thinktank. Glasgow: Centre for Cultural Policy Research, University of Glasgow. [Online]. http://www.gla.ac.uk/media/media_231168_en.pdf (13 January 2017).

Goldman, S. and Scardamalia, M. 2013. Managing, understanding, applying and creating knowledge in the Information Age: next-generation challenges and opportunities. Cognition and Instruction, 31(2): 255-269. DOI:10.1080/10824669.2013.773217.

Grafstein, A. 2002. A discipline-based approach to information literacy. Journal of Academic Librarianship, 28(4): 197204. DOI:10.1016/S0099-13330200283-5.

Gunn, C., Hearne, S., and Sibthorpe, J. 2011. Right from the start: a rationale for embedding academic literacy skills in university courses. Journal of University Teaching \& Learning Practice, 8(1). [Online]. http://ro.uow.edu.au/jutlp/vol8/iss1/6/ (13 January 2017).

Herrington, J. and Oliver, R. 2000. An instructional design framework for authentic learning environments. Educational Technology Research and Development, 48(3): 23-48. [Online]. DOI:10.1007/BF02319856.

Ivanic, R., Edwards, R., Barton, D., Martin-Jones, M., Fowler, Z., Hughes, B., Mannion, G., Miller, K., et al. 2009. Improving learning in college: Rethinking literacies across the curriculum. New York: Routledge. 
Jacobs, C. 2005. On being an insider on the outside: new spaces for integrating academic literacies. Teaching in Higher Education, 104: 475-487. [Online]. DOI:10.1080/13562510500239091.

Jiyane, G.V. and Onyancha, O.B. 2010. Information literacy education and instruction in South African libraries and LIS schools in institutions of higher education in South Africa. South African Journal of Libraries and Information Science, 76(1): 11-23.

Kalantzis, M. and Cope, B. 2012. Literacies. Port Melbourne, Victoria: Cambridge University Press.

Kress, G. 2010. Multimodality: a social semiotic approach to contemporary communication. New York: Routledge.

Land, R., Cousin, G., Meyer, J.H.F., and Davies, P. 2006. Conclusion: implications of threshold concepts for course design and evaluation. In Overcoming barriers to student understanding: threshold concepts and troublesome knowledge. J.H.F. Meyer and R. Land, Eds. New York: Routledge, 195-206.

Lankshear, C. and Knobel, M. 2007. Sampling the 'new' in new literacies. In A new literacies sampler. M. Knobel and C. Lankshear. New York: Peter Lang. 1-24.

Lea, M.R and Street, B.V. 2006. The 'academic literacies' model: theory and applications. Theory into Practice, 45(4): 368-377. [Online]. http://www.jstor.org/stable/40071622 (13 January 2017).

Leibowitz, B. 2004. Becoming academically literate in South Africa: lessons from student accounts for policymakers and educators. Language and Education, 18(1): 35-52. DOI:10.1080/09500780408666866.

Littlejohn, A., Beetham, H. and McGill, L. 2012. Learning at the digital frontier: a review of digital literacies in theory and practice. Journal of Computer Assisted Learning, 28(6): 547-556. [Online], DOI:10.1111/j.1365-2729.2011.00474.x.

Littlejohn, A., Beetham, H and McGill, L. 2014. Digital literacies as situated knowledge practices: academics' influence on learners' behaviours. In Literacy in the digital university: learning as social practice in a digital world. R. Goodfellow and M. Lea, Eds. Abingdon: Routledge, 126-136.

Lloyd, A. 2012. Information literacy as a socially enacted practice: sensitising themes for an emerging perspective of people-in-practice. Journal of Documentation, 68(6): 772-783. DOI:10.1108/00220411211277037.

Mackey, T.P. and Jacobson, T.E. 2011. Reframing information literacy as a metaliteracy. College \& Research Libraries, 76(1): 62-78. DOI:10.5860/crl-76r1.

McGuinness, C. 2006. What faculty think: exploring the barriers to information literacy development in undergraduate education. The Journal of Academic Librarianship, 12(6): 573-582. DOI:10.1016/j.acalib.2006.06.002.

Mezirow, J. 1997.Transformative learning: theory to practice. New Directions for Adult \& Continuing Education, 74: 5-12. DOI:10.1002/ace.7401/abstract.

Morrow, W. 2009. Bounds of democracy: epistemological access in higher education. Cape Town: Human Sciences Research Council

Salisbury, F.A., Karasmanis, S., Robertson, T., Corbin, J., Hulett, H. and Peseta, T.L. 2012 Transforming information literacy conversations to enhance student learning: New curriculum dialogues. Journal of University Teaching \& Learning Practice, 9 3: article 4. [Online]. http://ro.uow.edu.au/cgi/viewcontent.cgi?article=1363\&context=jutlp (13 January 2017).

Saunders, L. 2012. Faculty perspectives on information literacy as a student learning outcome. Journal of Academic Librarianship, 38(4): 226-236.

Scott, I. 2009. Towards an agenda for SoTL in Africa? International Journal Scholarship of Teaching and Learning, 31: article 3. [Online]. http://digitalcommons.georgiasouthern.edu/cgi/viewcontent.cgi?article=1131\&context=ij-sotl (13 January 2017).

Simmons, M.H. 2005. Librarians as disciplinary discourse mediators: using genre theory to move toward critical information literacy. portal: Libraries and the Academy, 14(2): 297-311. DOI:10.1353/pla.2005.0041.

South African Qualifications Authority (SAQA). 2000. The national qualifications framework and standards setting. Pretoria: SAQA. [Online] http://www.saqa.org.za/docs/pol/2003/standard_setting.pdf (13 January 2017).

Speight, S., Luckovic, N., and Cooker, L. 2013. The contested curriculum: academic learning and employability in higher education. Tertiary Education and Management, 19(2): 112-126. DOI:10.1080/13583883.2012.756058.

Swanson, T. 2010. Information is personal: critical information literacy and personal epistemology. In Critical library instruction: theories and methods. M.T. Accardi et al., Eds. Duluth, MN: Library Juice Press, 265-277.

Swanson, T. 2017. Sharing the ACRL Framework with faculty: opening campus conversations. College \& Research Libraries News, 78(1): 12-48. [Online]. http://crln.acrl.org/content/78/1/12.full.pdf+html (13 January 2017).

University of the Western Cape (UWC). 2010. UWC Charter of Graduate Attributes. [Online]. https://www.uwc.ac.za/TandL/Pages/Graduate-Attributes.aspx (13 January 2017).

University of the Western Cape (UWC). 2016. Teaching and Learning, Annual Report. (Unpublished).

Wingate, U. 2006. Doing away with 'study skills'. Teaching in Higher Education, 11(4): 457-469. DOI:10.1080/13562510600874268. 


\section{Appendix}

\section{Interview Questions}

1. What does the term "Twenty-first century literacies" mean to you?

2. How do you respond to current practices such as the use of social media in teaching and learning?

3. What sort of changes do you think there have been in reading, writing and presenting information in higher education during the past five years?

4. In what ways do you socialize students into disciplinary ways of thinking, reading and writing?

5. What types of scaffolding do you use to develop students' literacies?

6. What sort of literacy tasks do lecturers struggle with?

7. What is your understanding of inquiry-focused learning?

8. Have you used inquiry-focused learning in your teaching practice, and if so, how?

9. Can you relate some examples from your own practice where the learning environment has brought about transformation in students thinking and being? What do you ascribe this transformation to?

10. In thinking about the graduate attributes, students should be critically and relevantly literate. How would you go about moving students from a position of having knowledge of a field, to critiquing this knowledge, to taking a position in the field?

11. How would you bring students to a position of being able to critically discern authoritative views in the field that they are studying?

12. Do you think it is important for students to be able to produce knowledge? If so, how do you incorporate this into your curriculum design?

13. Do you think that learning should be collaborative? If so, what opportunities do you provide for students to coconstruct knowledge collaboratively?

14. Which schools of thought inform your ideas and practices? 